DOI https://doi.org/10.30525/978-9934-588-90-7-33

\title{
КОМПОЗИТИ ЕКОНОМІЧНОЇ ЛЕКСИКИ СУЧАСНОЇ НІМЕЦЬКОЇ МОВИ: СЛОВОТВІРНЕ ЗНАЧЕННЯ
}

\author{
Горбач О. В. \\ кандидат філологічних наук, дочент, \\ дочент кафедри правничої лінгвістики \\ Національна академія внутрішніх справ \\ м. Київ, Україна
}

Словотвірна структура слова визначається через мотиваційні відношення твірної основи і словотворчого форманта або іншого засобу, що видозмінюе похідне слово у порівнянні з мотивуючим його первинним словом [7, с. 158]. Стосовно складного слова важливими є не тільки значення складових компонентів, а й мотиваційні відношення між ними.

Слід зазначити, що до лексичного значення наближається словотвірне значення. Близькість зазначених типів мовного значення, як зазначає Кубрякова О. при дослідженні ознак словотвірного значення [5, с. 86], грунтується на основі конкретності та зв'язків з предметним світом.

Близькість лексичного та словотвірного значення визнає також i Зємская О., а їх відмінність одне від одного вбачає не у власне значенні, що виражається тим чи іншим словом, а у способі вираження цього значення. При цьому необхідною ознакою словотвірного значення $\epsilon$ наявність у нього словотвірних засобів вираження [2, с. 30-31].

Словотвірне значення $є$ узагальненою категорійною семантикою словотворчого форманта, змістом, що відрізняє значення похідного слова від семантики твірного. Словотвірне значення може бути більш конкретним (назви продуктів, назва особи за місцем проживання тощо) чи абстрактним (значення дії, додаткової дії, одиничності, збірності тощо). У складних словах словотвірне значення назване синтагматичним [6, с. 54-55]: воно демонструє поєднання семантики двох поєднуваних твірних основ.

Більшість дослідників відносять композитотворення до словотвору, тим самим конкретизуючи наявність у композитній конструкції словотворчої функції. При цьому мається на увазі план вираження: слово існує як цільнооформлена одиниця на противагу словосполученню, яке $\epsilon$ роздільнооформленим.

Характеризуючи словотвірне значення композитів, виділяються такі найбільш істотні ознаки: 
- формальна виразність;

- проміжне положення, яке займає композит між лексичним i граматичним значеннями;

- класифікуючий і систематизуючий характер значення;

- серійність [1, с. 229].

Ключовим поняттям при визначенні словотвірного значення прийнято вважати похідне слово як вторинне лексичне творення. Більшість композитів $є$ при цьому похідними від уже існуючих основ $\mathrm{i}$ самі при наявності ряду умов стають ядром нових слів, виявляючи при цьому найбільш активні моделі словотвору, як наприклад, утворення 3компонентних композитів на базі 2-компонентного складного іменника Kaufkraft «купівельна спроможність», Kaufkraftvergleich «порівняння купівельної спроможності», Kaufkraftanstieg «збільшення купівельної спроможності», $\quad$ Kaufkraftentwicklung «динаміка купівельної спроможності», Kaufkraftverlust «падіння купівельної спроможності».

Словотвірне значення як структурована особливим чином одиниця змісту виконує одночасно і функцію передачі складного, неелементарного значення, і функцію узагальнення певних типів відношень та зв'язків, наявних в оточуючому нас світі між тими чи іншими величинами, і функцію розчленованого уявлення позначуваного у вигляді цільнооформленого знаку.

Оскільки складне слово є носієм певного словотвірного значення, воно характеризується здатністю виконувати мовні функції: складне слово називає та характеризує одночасно. У цьому розумінні воно виступає в ролі аналогу до речення, оскільки містить завжди дві частини - ономасіологічний базис та ономасіологічну ознаку, поєднані в одній словотвірній структурі. Тому складне слово виявляється здатним позначати не тільки окремі предмети, процеси, ознаки, а й окремі ситуації та події, не тільки ідентифікуючи фрагмент дійсності, який виділяється та окремо усвідомлюється, а й характеризуючи цей фрагмент за його зв'язками 3 оточуючим світом та виявленими у ньому раніше предметами, ознаками та властивостями.

Проблематичним $\epsilon$ виявлення словотвірних значень складних слів, оскільки принципи цього процесу характеризуються недостатнім рівнем дослідження. Спробуємо виявити словотвірне значення складних іменників на прикладі двох видів композит: 1) утворених з непохідних основ; 2) утворених з основ, одна з яких є похідною.

Розглянемо процес формування словотвірного значення першої групи композитів на прикладі. Перший та другий компонент композита Artikelpreis являють собою непохідні основи. Кожна 3 цих основ не 
володіє словотвірним значенням. Словотвірне значення складних іменників такого типа формується в результаті складання їх основ. При чому перші компоненти виконують функцію уточнення по відношенню до останнього компонента (Grundwort), який дає частиномовну характеристику композита.

Принципово відрізняється формування словотвірного значення складних іменників, утворених виключно способом складання без суфіксації, від складних іменників, основний компонент яких є похідним. При цьому останні утворюються за одним способом словотвору складанням основ без участі суфіксації.

Інакше формується словотвірне значення другої групи композитів, основний компонент яких представлений похідною основою, наприклад: Handelsvertreter. Основний компонент таких композитів вже володіє словотвірним значенням - в данному випадку словотвірним значенням діяча, яке зберігається в якості загального словотвірного значення декількох словотвірних типів, кожний 3 яких характеризується конкретним словотвірним значенням. Останнє формується при взаємодії основного та залежного компонентів та визначається смисловими відношеннями між ними. У даному випадку ці відношення є об'єктними, що встановлюється через порівняння складного іменника 3 відповідним словосполученням (реченням): er vertritt den Handel. Таким чином, композити даного виду володіють словотвірним значенням діяча, виконуючого дію, позначену дієслівною основою першого компонента та спрямовану на об'єкт, названий останнім компонентом.

Відмічаючи недостатній рівень розробки принципів виявлення словотвірних значень складних слів, деякі дослідники приходять до висновку про те, що для виявлення словотвірного значення складного слова необхідно брати до уваги не тільки частиномовну характеристику та семантику складових компонентів композита, а й структурну характеристику та змістові відношення між першим та другим компонентами складних іменників.

Словоскладання служить відображенню та вираженню пов'язаності предметів, явищ та процесів в оточуючому нас світі та через надзвичайну складність можливих типів зв'язку в існуючому світі може приводити до виникнення семантичних структур різного змісту.

Словотвірне значення композита передає складне неелементарне значення, узагальнює типи відношень та зв'язків, наявних у навколишній дійсності між різними величинами, та представляє розчленоване поняття у вигляді цільнооформленого знаку. Обов'язковою ознакою словотвірного значення $€$ наявність у нього словотвірних засобів 
вираження. При виявленні словотвірного значення важливими $\epsilon$ частиномовна характеристика композита, семантика складових компонентів, структурна характеристика та змістові відношення між ініціальним та фінальним компонентами.

\title{
Література:
}

1. Алефіренко Н.Ф. Спорные проблемы семантики : монография. Москва : Гнозис, 2005. 326 с.

2. Земская Е.А. Словообразование как деятельность. Москва : Изд-во ЛКИ, 2007. 224 с.

3. Іщенко Н.Г. Словотвірне значення та форма його реалізації. Вісник Київського національного лінгвістичного університету. Серія Філологія. Київ, 2002. Т. 4. С. 127-137.

4. Коломойцев В.Э. Универсальный словарь экономических терминов: инвестирование, конкуренция, менеджмент, маркетинг, предпринимательство : учеб. пособие. Київ : Молодь, 2002. 416 с.

5. Кубрякова Е.С. Типы языковых значений: Семантика производного слова. Москва : Наука, 1981. 200 с.

6. Лопатин В.В. Русская словообразовательная морфемика. Москва : Наука, 1977. 315 с.

7. Плющ М. Я., Бевзенко С.П., Грипас Н.Я. Сучасна українська літературна мова: підручник. Київ : Вища школа, 2004. 430 с.

DOI https://doi.org/10.30525/978-9934-588-90-7-34

\section{МОРФОЛОГІЧНІ ОСОБЛИВОСТІ АНГЛОМОВНИХ РЕКЛАМНИХ СЛОГАНІВ}

\author{
Грищук Д. А. \\ студентка кафедри германської філології \\ Сумський державний університет \\ м. Суми, Украӥна
}

Реклама як один із найважливіших різновидів масової комунікації міцно увійшла в життя сучасної людини. Реклама, нині - невід'ємна частина людського побуту, за останні десятиліття набула унікальних особливостей та характеристик. Останнім часом рекламний слоган привертає до себе особливу увагу лінгвістів (А. Годдард, Р. Голдман, Дж. Ліч, а також Т. А. Безугла, I. В. Городецька, М. М. Кохтєв, 